\title{
INTRA-ARTICULAR TEMPERATURE AS A MEASURE OF JOINT REACTION
}

\author{
By STEVEN M. HORVATH AND JOSEPH L. HOLLANDER 1 \\ (From the Department of Physical Medicine and the Arthritis Section of the Hospital of the \\ University of Pennsylvania, Philadelphia)
}

(Received for publication September 8, 1948)

Clinicians studying Rheumatic Diseases have long used the surface temperature over the joints as indicative of the degree of synovial reaction. Many of the terms used in rheumatology imply temperature changes in the joint tissues, viz. "the acute hot joint of gout," "the cold swelling of chronic rheumatoid arthritis," the so-called "friction effect" or "heating-up" of osteoarthritic joints following exercise, or "articular jelling" (implying excessive joint cooling and stiffening on prolonged rest). Many measurements have been made of the skin temperature over diseased joints, but no study on intra-articular temperatures in human joints has been reported. Several studies $(1-4)$ have been made of intra-articular temperatures in dogs and one study (5) was performed on the stifle joint of a horse to determine the coefficient of friction within the joint, with and without synovial fluid.

\section{METHOD}

In an effort to find a method for more accurate evaluation of activity of joint disease, and for determination of the effects of rest, exercise, physical therapy, drugs, and Roentgen rays on joints, the following technique for determining intra-articular temperature has been developed.

Temperature studies were performed on the joints of normal volunteers and arthritic patients. All the studies were carried out in a room having a mean temperature of $24^{\circ} \mathrm{C}$. The subjects were reclining quietly for at least one half hour prior to the studies. Because of the ease of approach, the knee joint was the usual site of study. The skin was sterilized with an antiseptic (merthiolate) solution. The skin and joint capsule at a point one half inch medial to the medial border of the patella and high enough to avoid the fat pad was infiltrated with several cubic centimeters of $1 \%$ procaine solution. A 19 gauge needle was inserted through the synovial membrane into the joint space under the patella. Even in most normal joints, a few drops of fluid could be aspirated into a dry syringe. When it was certain that the point of the needle was under the patella and in the joint space, the

1 Aided by a grant from the National Foundation for Infantile Paralysis. syringe was removed and a fine copper constantan thermocouple or a thermistor was threaded through the needle to a depth of several inches in order to project freely into the joint space. The needle then was either left in place or, more frequently, removed leaving the temperature-sensitive element in place. The emf developed by the thermocouples was measured by a Leeds and Northrup type $K$ potentiometer, and the change in resistance of the thermistor was measured with a Wheatstone bridge. Thermocouples or thermistors were also fixed on the skin over-lying the patella, and in most cases a thermocouple was also placed on the skin of the opposite knee. Control temperature readings were taken after the joint had been at rest, with the element in place, for at least one half hour. If a therapeutic procedure was employed to modify joint temperature which would not permit leaving the metal thermocouple in place, it was removed. Immediately after the treatment, another aspiration and insertion was made at the same site in order to determine the magnitude of the elevation and to obtain a measure of the rate of cooling.

\section{RESULTS}

The amount of synovial fluid present appeared to make little difference in the joint temperature except to alter the rate of change. The position of the temperature-sensitive element in the joint was relatively unimportant. The thermocouple or thermistor often was inserted a distance of three or more inches into the joint space. Temperature measurements made during withdrawal of the element showed no appreciable variation until the measuring element was out of the joint. Thirtyone determinations of the internal temperature of the knee joint and the over-lying skin surface have been obtained on 25 individuals. Two studies were made of the elbow joint in one patient. In no instance was the rectal temperature elevated at the time of study. Four subjects were essentially normal except for possible age changes (all were between 35 and 42 years). Twelve patients had rheumatoid arthritis. Seven had degenerative joint disease; one had Reiter's syndrome and one had gouty arthritis. The degree of local clinical 
TABLE I

Temperatures obtained in the joint cavity and on the surface over the joint

\begin{tabular}{|c|c|c|c|c|c|c|}
\hline \multirow{2}{*}{ Case } & \multirow{2}{*}{ Diagnosis } & \multirow{2}{*}{ Age } & \multirow{2}{*}{ Sex } & \multirow{2}{*}{$\begin{array}{l}\text { Relative } \\
\text { activity }\end{array}$} & \multicolumn{2}{|c|}{$\begin{array}{l}\text { Tempera- } \\
\text { ture, }\end{array}$} \\
\hline & & & & & Joint & $\begin{array}{l}\text { Sur- } \\
\text { face }\end{array}$ \\
\hline $\begin{array}{r}1 \\
2 \\
3 \\
4 \\
5 \\
6 \\
7 \\
8 \\
9 \\
10 \\
11 \\
12\end{array}$ & $\begin{array}{l}\text { Normal } \\
\text { Normal } \\
\text { Normal } \\
\text { Normal } \\
\text { Degenerative Arth. } \\
\text { Degenerative Arth. } \\
\text { Degenerative Arth. } \\
\text { Degenerative Arth. } \\
\text { Degenerative Arth. } \\
\text { Degenerative Arth. } \\
\text { Degenerative Arth. } \\
\text { Reiter's Syndrome } \\
\\
\text { Chronic Gout }\end{array}$ & \begin{tabular}{|l|}
35 \\
38 \\
44 \\
32 \\
54 \\
60 \\
48 \\
51 \\
67 \\
60 \\
52 \\
21
\end{tabular} & $\begin{array}{l}\mathrm{M} \\
\mathrm{M} \\
\mathrm{M} \\
\mathrm{M} \\
\mathrm{F} \\
\mathrm{F} \\
\mathrm{F} \\
\mathrm{F} \\
\mathrm{F} \\
\mathrm{F} \\
\mathrm{F} \\
\mathrm{M}\end{array}$ & $\begin{array}{l}\text { Moderate } \\
\text { Moderate } \\
\text { Questionable } \\
\text { Questionable } \\
\text { Questionable } \\
\text { Questionable } \\
\text { Questionable } \\
\text { Severe } \\
\text { Moderate } \\
\text { Slight } \\
\text { Moderate }\end{array}$ & $\begin{array}{l}91.1 \\
88.6 \\
90.7 \\
90.8 \\
93.4 \\
94.2 \\
93.4 \\
93.7 \\
93.0 \\
95.6 \\
94.6 \\
93.3 \\
90.6 \\
89.4 \\
96.0 \\
96.1\end{array}$ & $\begin{array}{l}86.2 \\
87.5 \\
89.5 \\
85.2 \\
89.0 \\
90.9 \\
89.9 \\
90.8 \\
86.0 \\
90.8 \\
92.3 \\
89.7 \\
90.8 \\
87.4 \\
89.2 \\
90.0\end{array}$ \\
\hline
\end{tabular}

activity in the joint tested was estimated by the presence and severity of the following: swelling, tenderness, effusion and limitation of motion by pain.

The values obtained are presented in Tables $I$ and II. The correlation $(r=0.65)$ of joint temperature with surface temperature was generally good, but there were notable exceptions. In one patient the joint temperature was as much as $7.6^{\circ} \mathrm{F}$. higher than the skin temperature, while in two others the surface temperature was higher than the intra-articular temperature. Relatively few normal joints have as yet been studied to determine the variations in resting temperatures. The difficulty of obtaining volunteers has somewhat hampered this evaluation. However, skin temperatures thus far obtained in "normal" subjects range from $85.2^{\circ}$ $\mathrm{F}$. to $89.5^{\circ} \mathrm{F}$. and joint temperatures from $88.6^{\circ} \mathrm{F}$. to $91.1^{\circ} \mathrm{F}$.

In degenerative joint disease clinical activity was difficult to evaluate. Patients with this disease had, in most cases, normal skin temperatures but their joint temperatures were all moderately elevated. In the cases of chronic gout and Reiter's syndrome the skin temperatures were normal although joint temperatures were definitely elevated. ${ }^{1}$ The clinical improvement in the patient

\footnotetext{
1 A knee joint temperature of $98.6^{\circ} \mathrm{F}$. was observed
} recently in a patient in an active stage of gout. with Reiter's syndrome was reflected in the lowered joint temperatures. In rheumatoid arthritis the highest joint temperature, $97.1^{\circ} \mathrm{F}$., was recorded in an elbow joint. The highest surface temperature was $95^{\circ} \mathrm{F}$. In case No. 25 where the rheumatoid process was completely quiescent, both the skin and joint temperatures were subnormal. In rheumatoid arthritis there was a positive correlation of both surface and joint temperature with relative clinical activity (Figure 1 ). The correlation appears to be somewhat better with joint rather than with surface temperature. In one individual the surface temperature was higher than the joint (Table II).

A variety of physical measures were employed to modify the joint temperature. Although results will be reported in detail in a subsequent paper (6), some observations of interest, primarily in reference to the joint reaction itself, are reported herein. Fever therapy, induced by a pyrogen injected intravenously, resulted in increased joint and sur-

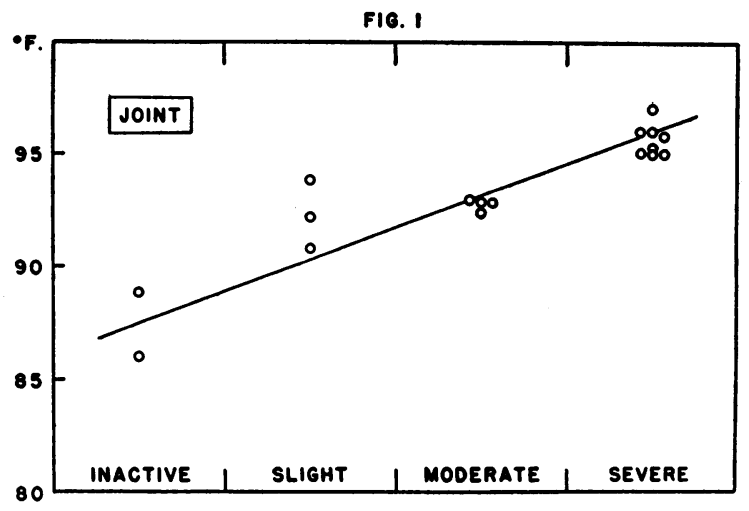

CLINICAL ACTIVITY

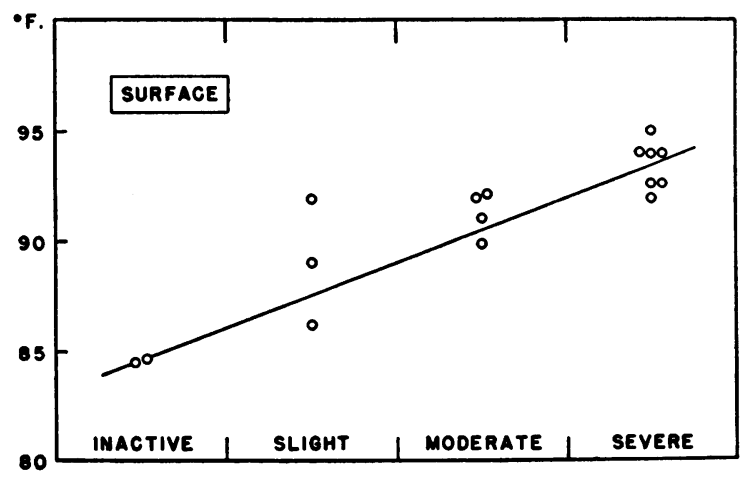

Fig. 1. Temperature of JoInt and Skin over Joint in Patients Having Rheumatoid Arthritis with Varying Degrees of Clinical Activity 
TABLE II

Temperatures obtained in the joint cavity and on the surface over the joint of patients with rheumatoid arthritis

\begin{tabular}{|c|c|c|c|c|c|}
\hline \multirow{2}{*}{ Case } & \multirow{2}{*}{ Age } & \multirow{2}{*}{ Sex } & \multirow{2}{*}{$\begin{array}{l}\text { Relative } \\
\text { activity }\end{array}$} & \multicolumn{2}{|c|}{ Temperature, ${ }^{\circ} \mathrm{F}$. } \\
\hline & & & & Joint & Surface \\
\hline 14 & 56 & $\mathbf{F}$ & Severe & 95.0 & 93.7 \\
\hline 15 & 42 & $\mathbf{M}$ & Severe & $\begin{array}{l}90.0 \\
95.1 \\
95.3\end{array}$ & $\begin{array}{l}94.0 \\
91.1 \\
92.6\end{array}$ \\
\hline $16^{*}$ & 65 & $\mathbf{M}$ & Severe & 97.1 & $\overline{95.0}$ \\
\hline $\begin{array}{l}17 \\
18\end{array}$ & $\begin{array}{l}18 \\
40\end{array}$ & $\begin{array}{l}F \\
F\end{array}$ & $\begin{array}{l}\text { Severe } \\
\text { Severe } \\
\text { Moderate }\end{array}$ & $\begin{array}{l}93.0 \\
95.8 \\
96.0 \\
92.8\end{array}$ & $\begin{array}{l}92.6 \\
93.9 \\
92.1\end{array}$ \\
\hline $\begin{array}{l}19 \\
20 \dagger \\
21 \\
22 \\
23 \\
24 \\
25\end{array}$ & $\begin{array}{l}61 \\
30 \\
61 \\
68 \\
50 \\
71 \\
57\end{array}$ & $\begin{array}{l}\mathbf{M} \\
\mathbf{M} \\
\mathbf{M} \\
\mathbf{F} \\
\mathbf{M} \\
\mathbf{M} \\
\mathbf{M}\end{array}$ & $\begin{array}{l}\text { Moderate } \\
\text { Moderate } \\
\text { Moderate } \\
\text { Slight } \\
\text { Slight } \\
\text { Slight } \\
\text { Inactive }\end{array}$ & $\begin{array}{l}92.0 \\
92.9 \\
92.8 \\
92.4 \\
93.8 \\
90.8 \\
92.2 \\
88.8 \\
86.0\end{array}$ & $\begin{array}{l}91.9 \\
91.0 \\
89.8 \\
86.2 \\
91.9 \\
89.0 \\
84.5 \\
84.7\end{array}$ \\
\hline
\end{tabular}

${ }^{*}$ Elbow joint (all others were knee joints).

† Atypical.

face temperatures. When rectal temperature was elevated to $103^{\circ} \mathrm{F}$., a joint temperature of $101^{\circ} \mathrm{F}$. (an increase of $5.2^{\circ} \mathrm{F}$.) and a skin temperature of $99.4^{\circ} \mathrm{F}$. (an increase of $8.3^{\circ} \mathrm{F}$.) was noted.
On another occasion, with a rectal temperature of $105.2^{\circ} \mathrm{F}$. a joint temperature of $97.1^{\circ} \mathrm{F}$. was obtained, but at this time the patient was being cooled by application of ice bags to the thighs. Even under these circumstances, the knee joint temperature was elevated $2^{\circ} \mathrm{F}$. over the control observation.

Observations were made on the influence of hot and cold packs on both normal and inflamed joints. The application of hot packs invariably resulted in a depression of the intra-articular temperature of as much as $2.2^{\circ} \mathrm{F}$. Continued reapplication of these hot packs produced steadily diminishing effects, although even after the tenth hot pack of a series, the joint temperature was still definitely lowered. The internal temperature quickly returned to control levels after discontinuation of the packs and five to ten minutes later the values were slightly higher, a positive reflex effect (Figure 2). Cold packs, on the other hand, raised joint temperatures appreciably. Hot or cold packs applied to one knee produced reflex effects in the opposite knee of similar character. These studies were performed in the winter months. When observations were resumed during the summer, it was surpris-
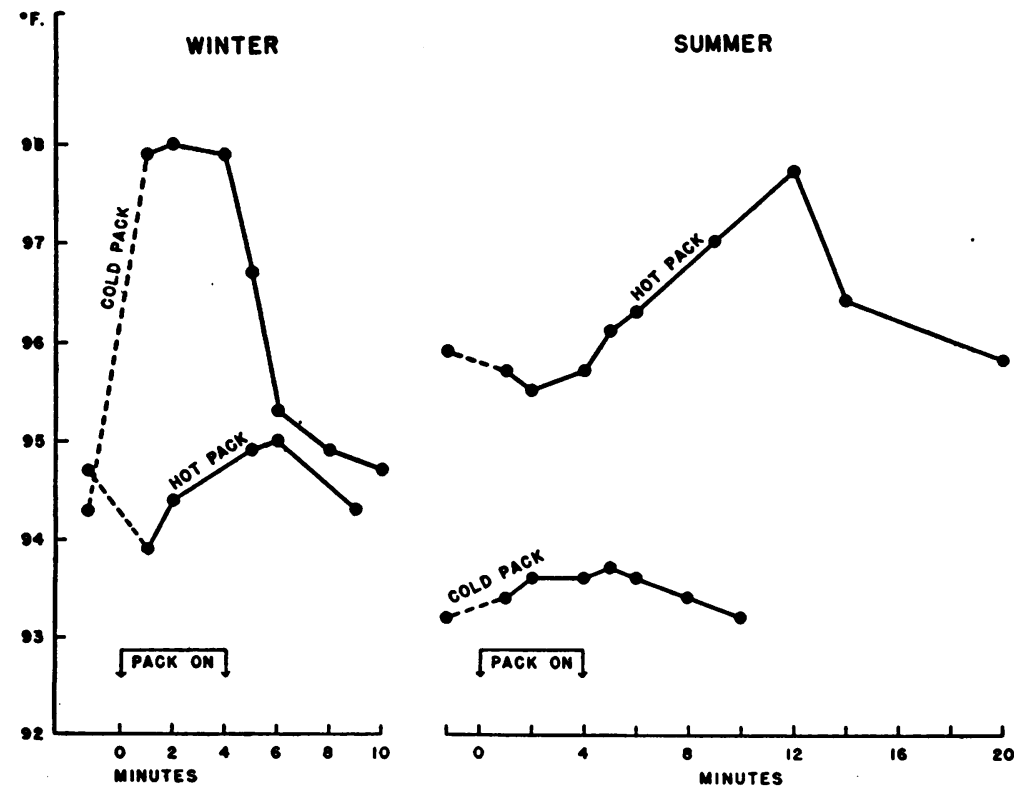

Fig. 2. Reflex Phenomena Associated with the Application of Hot and Cold Packs over the Joint

All points indicate joint temperatures. The dotted lines indicate the shift of the temperature from control values during the first minute of pack application. 
TABLE III

Seasonal influence on the temperature reaction of the knee joint to hot or cold wet compresses. Maximum changes occurred within the first two of the five minutes during which the packs were applied

\begin{tabular}{|c|c|c|c|c|}
\hline & \multirow{2}{*}{ Exp. } & \multirow{2}{*}{ Type of pack } & \multicolumn{2}{|c|}{ Maximum change, ${ }^{\circ} \mathrm{F}$} \\
\hline & & & Knee joint & Surface \\
\hline Winter & $\begin{array}{l}1 \\
2 \\
3 \\
4 \\
5\end{array}$ & $\begin{array}{l}\text { Hot }\left(108^{\circ} \mathrm{F} .\right) \\
\text { Hot } \\
\text { Cold }\left(65^{\circ} \mathrm{F} .\right) \\
\text { Cold } \\
\text { Cold }\end{array}$ & $\begin{array}{r}-2.3 \\
-0.8 \\
2.5 \\
5.0 \\
2.6\end{array}$ & $\begin{array}{r}12.2 \\
5.1 \\
-\quad 9.1 \\
-10.1 \\
-6.1\end{array}$ \\
\hline Summer & $\begin{array}{r}6 \\
7 \\
8 \\
9 \\
10 \\
11\end{array}$ & $\begin{array}{l}\text { Hot } \\
\text { Hot } \\
\text { Hot } \\
\text { Hot } \\
\text { Cold } \\
\text { Cold }\end{array}$ & $\begin{array}{r}-0.4 \\
-0.5 \\
-0.5 \\
0.2 \\
0.5 \\
0.4\end{array}$ & $\begin{array}{r}6.4 \\
5.8 \\
5.1 \\
7.5 \\
-\quad 3.6 \\
-8.1\end{array}$ \\
\hline
\end{tabular}

ing to note that although the pattern of the reflex was similar, the magnitude of the response was diminished (Figure 2 and Table III). This difference seems to be related to the relative degree of vascular tone exhibited by individuals at the various seasons of the year $(7,8)$.

Painful stimuli, apprehension, alarm or smoking lowered the skin and elevated the joint temperature in all cases so studied. Simple passive and non-weight-bearing active movement of the joint was performed in several instances. Temperature increases of as much as $2.5^{\circ} \mathrm{F}$. were noted. The joint temperature following periods of active exercise showed varying degrees of elevation with rapid cooling on rest.

\section{DISCUSSION}

These preliminary observations of joint tissue temperatures in some of the forms of arthritis appear to indicate that an accurate evaluation of the degree of inflammation in a joint may be obtained by this method. A close correlation between the internal joint temperature and the clinical evaluation of activity of disease was not surprising and indicated that the temperature of the synovial fluid was directly dependent on the relative hyperemia of the synovium. However, the data would indicate that it is extremely difficult to evaluate the lower degree of clinical activity. The amount of heat "felt" externally over a joint was usually, but not necessarily, related to joint temperature. In degenerative joint disease, the elevation of joint temperature noted seemed more closely correlated to the apprehension of the patient and the amount of adipose tissue about the knee than to the clinical activity as determined by external examination. The slow drop seen with continued rest in these patients would imply that this elevated temperature was real and was related to increased friction effect and retarded cooling.

Incidental observations were made on pain sensitivity of the synovium and cartilage, confirming the observations of Smyth and Freyberg $(9,10)$. The synovium was quite tender whenever touched at any point that had not been anesthetized with procaine. If the thermocouple was inserted far enough to touch the synovium on the opposite side of the patella, a sharp pain was produced. The articular cartilage, however, seemed entirely insensitive when touched, or even when accidentally penetrated by the aspirating needle or tip of the thermocouple.

In conjunction with the studies on the effectiveness of physical therapy procedures (6), one particularly interesting phenomenon was observed. Application of hot packs increased surface temperature markedly, but decreased the deep. A secondary rise of joint temperature occurred following removal of the packs. Cold packs to the knee surface, however, produced a definite cooling of the skin and a lasting increase in joint temperature. The intensity of hot and cold applications was not sufficient to induce pain in most instances but apparently this phenomenon is a sympathetic reflex effect associated with the principle of counterirritation. The magnitude of this effect is apparently related to the state of vascular tone and dependent upon the season of year that observations were made $(7,8)$.

It appears significant that cold, pain, fear and smoking produced identical effects (i.e., lowering of the skin and elevation of the joint temperatures). Perhaps this observation may lead to an explanation of how such factors aggravate the symptoms of an arthritic process. The effects of vaso-dilating and vaso-constricting drugs, deep X-ray therapy, exercise and other agents on the synovial circulation are being studied by this method. Finer measuring units have been developed which will make it possible to study temperatures in fingers, wrists, and other small joints. 
No ill effects from these studies were noted in any of the patients. One study on a normal volunteer resulted in a slight synovitis of two days' duration, after weight-bearing exercise with the thermistor in place. Many of our patients expressed improvement after this "treatment," showing the psychic benefit derived from any robust procedure and the special interest exhibited by the physician.

\section{SUM MARY}

1. A method for the determination of the temperature of the articular cavity has been developed which appears to have a practical use both to measure the degree of inflammation in the joint and to determine the effect of external influences on joints.

2. Intra-articular temperatures correlated somewhat more closely than the surface temperatures over the joint with the clinical activity of rheumatoid arthritis.

3. The joint temperatures in degenerative joint disease were higher than anticipated from relative clinical activity. This might be related to greater joint friction effects and to retarded cooling.

4. The joint temperature fell when hot packs were applied over the joint, and rose with the application of cold packs. The magnitude of these responses was affected by seasonal influences being greater in the winter than the summer.

\section{BIBLIOGRAPHY}

1. Kaplan, E., and Joseph, N. R., Determination of circulation rate in articular structures. Federation Proc., 1948, 7, 63.

2. Lonergan, R. C., An experimental study of diathermy. J. of Indust. Hyg., 1927, 9, 1.

3. Pratt, C. B., and Sheard, C., Thermal changes produced in tissues by local applications of radiothermy. Proc. Soc. Exper. Biol. \& Med., 1935, 32, 766.

4. Sheard, C., and Pratt, C. B., Changes in temperature of tissues after systemic applications of short wave electric fields. Proc. Soc. Exper. Biol. \& Med., 1935, 32, 763.

5. Jones, E. S., Joint lubrication. Lancet, 1934, 1, 1426.

6. Hollander, J. L., and Horvath, S. M., The influence of various physical therapy procedures on the intraarticular temperature of man. (In press.)

7. Naide, M., Sayen, A., and Comroe, B. I., Characteristic vascular pattern in patients with rheumatoid arthritis. Arch. Int. Med., 1945, 76, 139.

8. Burch, G. E., Myers, H. L., Porter, R. R., and Schaffer, N., Objective studies of some physiologic responses in mild chronic trench foot. Bull. Johns Hopkins Hosp., 1947, 80, 1.

9. Smyth, C. J., and Freyberg, R., The significance and management of joint pain. J. Michigan M. Soc., 1943, 42, 818.

10. Freyberg, R. H., Joint pain; considerations of anatomic and physiologic basis, pathogenesis and diagnostic significance. Clinics, 1944, 2, 1586. 